\title{
PENERAPAN ACCELERATED LEARNING DALAM PENINGKATAN KEMAMPUAN KOMUNIKASI MATEMATIS SISWA SEKOLAH MENENGAH PERTAMA
}

\author{
Jaya Dwi Putra \\ Dosen Tetap Prodi Pendidikan Matematika Universitas Riau Kepulauan Batam
}

\begin{abstract}
ABSTRAK
Penelitian ini merupakan penelitian dengan desain pretest-posttest experiment group design, yang bertujuan untuk mengetahui pengaruh penerapan accelerated learning terhadap peningkatan komunikasi matematis siswa SMP. Populasi penelitian ini adalah seluruh siswa SMP Negeri 1 Kecamatan Harau, dan pengambilan sampel penelitian dilakukan dengan teknik purposive sampling, yaitu dengan memilih siswa kelas VIII sebanyak dua kelas sebagai sampel. Penelitian ini terdiri dari dua kelompok pembelajaran, yaitu pembelajaran accelerated learning dan pembelajaran konvensional. Setiap kelompok terdiri dari 28 siswa yang terbagi berdasarkan kategori Kemampuan Awal Matematis (KAM), yaitu kategori KAM tinggi, sedang dan rendah di kelasnya. Untuk mendapatkan data hasil penelitian digunakan instrumen berupa tes kemampuan komunikasi matematis, angket, observasi dan wawancara. Dalam perhitungan ujicoba instrumen diggunakan program Anates dan perhitungan statistik dengan menggunakan SPSS 17. Perbedaan rataan peningkatan kemampuan penalaran dan komunikasi matematis berdasarkan keseluruhan siswa ditentukan dengan menggunakan uji-t. Perbedaan rataan peningkatan kemampuan penalaran dan komunikasi matematis berdasarkan kategori KAM ditentukan dengan menggunakan uji Mann-Whitney. Hasil penelitian ini adalah peningkatan kemampuan komunikasi matematis siswa yang mendapat pembelajaran accelerated learning lebih baik daripada siswa yang mendapat pembelajaran konvensional ditinjau berdasarkan keseluruhan siswa serta kategori KAM sedang, sedangkan pada kategori KAM tinggi dan rendah tidak terdapat perbedaan yang signifikan.
\end{abstract}

Kata kunci: pembelajaran Accelerated Learning, kemampuan awal matematis, kemampuan komunikasi matematis.

*) Dosen FKIP UNRIKA

\section{A. PENDAHULUAN}


Menggali dan mengembangkan kemampuan komunikasi matematis siswa perlu mendapat perhatian guru dalam pembelajaran matematika. Siswa mestinya mendapat kesempatan yang banyak untuk menggunakan kemampuan bernalar dan komunikasinya. Untuk dapat mencapai standar-standar pembelajaran itu, seorang guru hendaknya dapat menciptakan suasana belajar yang memungkinkan bagi siswa belajar secara aktif dengan mengkonstruksi, menemukan dan mengembangkan pengetahuannya. Dengan belajar matematika diharapkan siswa mampu menyelesaikan masalah, menemukan dan mengkomunikasikan ide-ide yang muncul dalam pikiran siswa. Untuk itu dalam pembelajaran matematika diharapkan siswa memiliki kemampuan penalaran dan kemampuan komunikasi matematis, yang tentunya diharapkan dapat mencapai hasil yang memuaskan.

Kenyataan menunjukkan bahwa pembelajaran yang dikembangkan guru selama ini kurang mendukung berkembangnya kemampuan komunikasi matematis siswa, pembelajaran bersifat satu arah, siswa tidak terlibat secara aktif dalam menggali konsep-konsep atau ide-ide matematis secara mendalam dan bermakna, sehingga siswa menerima pengetahuan dalam bentuk yang sudah jadi dan lebih bersifat hafalan. Hal ini diperkuat dari hasil penelitian Diani (2010) yang menyatakan bahwa kemampuan penalaran dan komunikasi matematis siswa masih tergolong rendah. Selain itu Hutajulu (2010) dan Suhendar (2007) dari hasil penelitian mereka, masing-masing menyatakan bahwa kemampuan komunikasi matematis siswa masih rendah.

Di samping itu, salah satu indikator yang menunjukkan mutu pendidikan di Indonesia cenderung masih rendah adalah hasil penilaian internasional mengenai prestasi belajar siswa. Berdasarkan data dari Badan Penelitian dan Pengembangan (Balitbang) (2011), dapat diketahui bahwa hasil survei TIMSS pada tahun 2003 menunjukkan prestasi belajar siswa kelas VIII (delapan) Indonesia berada di peringkat 34 dari 45 negara. Walaupun rerata skor naik menjadi 411 dibanding 403 pada tahun 1999, Indonesia masih berada di bawah rerata untuk wilayah ASEAN. Prestasi belajar siswa Indonesia pada TIMSS 2007 lebih memprihatinkan lagi, karena rerata skor siswa turun menjadi 397, jauh lebih rendah dibanding rerata skor internasional yaitu 500. Prestasi Indonesia pada TIMSS 2007 berada di peringkat 36 dari 49 negara.

Tidak jauh berbeda dari TIMSS, pada Programme for International Student Assesment (PISA) prestasi belajar anak-anak Indonesia yang berusia sekitar 15 tahun masih rendah. Pada PISA tahun 2003, Indonesia berada di peringkat 38 dari 40 negara, dengan rerata skor 360. Pada tahun 2006 rerata skor siswa naik menjadi 391, yaitu peringkat 50 dari 57 negara, sedangkan pada tahun 2009 Indonesia hanya menempati peringkat 61 dari 65 negara, dengan rerata skor 371, sementara rerata skor internasional adalah 496 (Balitbang, 2011).

Hasil PISA yang rendah tentunya disebabkan oleh banyak faktor. Salah satunya adalah siswa Indonesia pada umumnya kurang terlatih dalam menyelesaikan soal-soal yang menuntut kemampuan penalaran dan komunikasi matematis, karena dua kemampuan tersebut termasuk kemampuan yang diujikan.

Tabel 1 Proporsi Skor Sub-sub Komponen Proses yang Diuji dalam Studi PISA

\begin{tabular}{|l|l|c|}
\hline Komponen & Kemampuan yang diujikan & Skor (\%) \\
\hline Proses & Mampu merumuskan masalah secara matematis. & 25 \\
\cline { 2 - 3 } & $\begin{array}{l}\text { Mampu menggunakan konsep, fakta, prosedur dan } \\
\text { penalaran dalam matematika. }\end{array}$ & 50 \\
\hline
\end{tabular}




\begin{tabular}{|l|l|c|}
\hline & $\begin{array}{l}\text { Menafsirkan, menerapkan dan mengevaluasi hasil } \\
\text { dari suatu proses matematika. }\end{array}$ & 25 \\
\hline
\end{tabular}

Dari Tabel 1 dapat dilihat bahwasannya pada proporsi skor sub-sub komponen yang diuji dalam studi PISA termasuk di dalamnya kemampuan penalaran dan komunikasi matematis. Mampu merumuskan masalah secara matematis berkaitan dengan kemampuan komunikasi matematis. Mampu menggunakan konsep, fakta, prosedur dan penalaran dalam matematika berkaitan dengan kemampuan penalaran matematis. Menafsirkan, menerapkan dan mengevaluasi hasil dari suatu proses matematika juga berkaitan dengan kemampuan penalaran dan komunikasi matematis.

Berdasarkan hasil PISA diketahui, bahwa kemampuan matematis khususnya kemampuan komunikasi siswa di Indonesia masih rendah. Semua kemampuan yang diharapkan dapat dimiliki oleh siswa tidak serta merta dapat terwujud hanya dengan mengandalkan proses pembelajaran yang selama ini terbiasa ada di sekolah, dengan urutan-urutan langkah seperti, diajarkan teori/definisi/teorema, diberikan contoh-contoh dan diberikan latihan soal. Proses belajar seperti ini tidak membuat anak didik berkembang dan memiliki kemampuan bernalar berdasarkan pemikirannya, tapi justru lebih menerima ilmu secara pasif.

Hal senada diungkapkan oleh Turmudi (2008) yang memandang bahwa pembelajaran matematika selama ini kurang melibatkan siswa secara aktif, sebagaimana dikemukakannya bahwa "pembelajaran matematika selama ini disampaikan kepada siswa secara informatif, artinya siswa hanya memperoleh informasi dari guru saja sehingga derajat "kemelekatannya" juga dapat dikatakan rendah". Pembelajaran seperti ini mengakibatkan siswa sebagai subjek belajar kurang dilibatkan dalam menemukan konsep-konsep pelajaran yang harus dikuasainya.

Agar kesulitan yang dihadapi siswa dapat diatasi dan kemampuan komunikasi matematis dapat ditingkatkan, dibutuhkan suatu metode pembelajaran yang mampu memberikan kebermaknaan belajar bagi siswa. Menurut Madnesen dan Sheal (Suherman, 2004) bahwa kebermaknaan belajar tergantung bagaimana cara siswa belajar. Implikasi terhadap pembelajaran adalah bahwa kegiatan pembelajaran identik dengan aktivitas siswa secara optimal. Oleh karena itu guru mesti menghadirkan metode pembelajaran yang dapat mendukung cara belajar siswa secara aktif.

Belajar aktif adalah belajar di mana siswa lebih berpartisipasi aktif sehingga kegiatan siswa belajar jauh lebih dominan daripada kegiatan guru mengajar. Hal tersebut sejalan dengan pendapat Kilpatrick (Turmudi, 2012) yang menyatakan bahwa "knowledge is actively constructed by cognizing subject and not passively received from the environment" yang artinya pengetahuan dikonstruksi oleh siswa secara aktif dalam mengenali subjek bukan secara pasif menerima dari lingkungan. Siswa dapat aktif dalam mengkonstruksi maupun mengorganisir belajarnya sendiri dengan memanfaatkan bahan ajar yang disediakan oleh guru. Siswa tidak hanya dapat memanfaatkan beragam sumber belajar, melainkan pembelajaran yang dilaluinya akan dirasakan sebagai belajar sambil bermain.

Salah satu bentuk pembelajaran yang dapat mengaktifkan siswa adalah Accelerated Learning. Dalam pembelajaran Accelerated Learning siswa dilibatkan secara aktif agar mencapai percepatan dalam mengenal dan menguasai konsep matematika yang diajarkan. Percepatan yang dimaksud diusahakan oleh guru kepada siswa melalui: pemberian tugas di rumah untuk membaca dan memahami materi 
pelajaran yang akan dipelajari berikutnya, memberi kesempatan untuk bertanya, menjawab pertanyaan, dan menjelaskan setiap jawaban yang diberikan, serta adanya interaksi, diskusi dan kerjasama dengan teman, sehingga kemampuan penalaran dan komunikasi matematis siswa dapat ditingkatkan. Meier (2002) berpendapat bahwa dalam melakukan aktivitas belajar, siswa pada dasarnya melalui empat tahap penting yaitu: Persiapan (preparation), Presentasi (presentation), Latihan (practice), Kinerja (performance).

Proses belajar dimulai dari adanya minat untuk mempelajari sesuatu. Siswa mengembangkan kemampuan bernalarnya dalam melakukan persiapan yang relevan dengan usaha yang diperlukan untuk melakukan aktivitas belajar. Adanya minat untuk mempelajari suatu pengetahuan atau keterampilan diikuti dengan tahap berikutnya yaitu presentasi. Dalam tahap ini siswa mengkomunikasikan ide-ide matematisnya serta mulai berkenalan dengan pengetahuan dan keterampilan yang diminati untuk dipelajari. Tahap selanjutnya adalah tahap latihan. Pada tahap ini siswa mengintegrasikan pengetahuan dan keterampilan yang dipelejari dengan pengetahuan dan keterapilan yang telah dikuasai sebelumnya. Tahap akhir dari proses belajar adalah tahap saat siswa memperlihatkan kinerja melalui aplikasi pengetahuan dan keterampilan yang telah dipelajari dalam situasi yang nyata.

Dalam penelitian ini, selain dari aspek pembelajaran, aspek Kemampuan Awal Matematis (KAM) siswa juga dijadikan sebagai fokus penelitian. Hal ini disebabkan karena hasil belajar siswa diduga terkait dengan KAM. Pemerolehan pengetahuan baru sangat ditentukan oleh pengetahuan awal (prior knowledge) siswa. Selain itu matematika merupakan ilmu yang terstruktur sehingga terdapat kaitan antara suatu topik matematika dengan topik matematika lainnya. Penguasaan siswa terhadap topik matematika tertentu akan menuntut penguasaan siswa terhadap topik-topik matematika sebelumnya. Oleh karena itu diduga hasil belajar matematika terdahulu akan terkait dengan hasil belajar berikutnya. Hal ini sejalan dengan temuan Begle (Darhim, 2004) melalui penelitiannya bahwa salah satu prediktor terbaik untuk hasil belajar matematika adalah hasil belajar matematika sebelumnya. Lebih lanjut dikatakan bahwa peran variabel kognitif lainnya ternyata tidak sebesar variabel hasil belajar sebelumnya.

\section{B. MASALAH}

Berdasarkan uraian di atas, masalah dalam penelitian ini adalah "apakah pembelajaran accelerated learning dapat meningkatkan kemampuan penalaran dan komunikasi matematis siswa SMP?" Masalah ini dapat dijabarkan ke dalam beberapa 
pertanyaan penelitian sebagai berikut: (1) Apakah peningkatan kemampuan komunikasi matematis siswa yang mendapat pembelajaran accelerated learning lebih baik daripada siswa yang mendapat pembelajaran konvensional ditinjau dari keseluruhan siswa?; (2) Apakah peningkatan kemampuan komunikasi matematis siswa yang mendapat pembelajaran accelerated learning lebih baik daripada siswa yang mendapat pembelajaran konvensional ditinjau dari KAM siswa?.

\section{METODE PENELITIAN}

Penelitian ini merupakan penelitian kuasi eksperimen karena pemilihan sampel tidak secara random, tetapi menerima keadaan sampel apa adanya. Desain penelitian yang digunakan adalah Non-equivalent Control Group Design (Ruseffendi, 2005). Populasi dalam penelitian ini adalah siswa SMP kelas delapan di Kabupaten Lima Puluh Kota Tahun Pelajaran 2012/2013. Pengambilan sampel dalam penelitian ini dilakukan dengan menggunakan teknik purposive sampling. Sampel yang digunakan dalam penelitian ini adalah kelas VIII 1 dan VIII 3 di salah satu SMP di Kabupaten Lima Puluh Kota. Instrumen yang digunakan dalam penelitian ini adalah instrumen tes dan non-tes. Adapun instrumen tes terdiri dari tes pengetahuan awal matematika dan tes kemampuan berpikir logis matematis siswa, sedangkan instrumen non-tes yaitu lembar observasi dan wawancara.

\section{HASIL DAN PEMBAHASAN}

Data kuantitatif diperoleh melalui tes kemampuan penalaran dan komunikasi matematis di awal dan di akhir pembelajaran. Data tersebut diperoleh dari 56 siswa, terdiri dari 28 siswa kelas eksperimen yang mendapat pembelajaran accelerated learning dan 28 siswa kelas kontrol yang mendapat pembelajaran konvensional. Berikut ini uraian hasil penelitian.

\section{Data Kemampuan Komunikasi Matematis Siswa}

Data kemampuan komunikasi matematis diperoleh melalui pre-test dan post-test. Dari skor pre-test dan post-test selanjutnya dihitung gain ternormalisasi ( $\mathrm{N}$-gain) kemampuan komunikasi matematis baik pada kelas eksperimen maupun kelas kontrol. Rataan N-gain yang diperoleh dari perhitungan ini merupakan gambaran peningkatan kemampuan komunikasi matematis siswa yang mendapatkan pembelajaran accelerated learning dan pembelajaran konvensional. Tabel 1 berikut ini merupakan deskripsi pre-test, post-test, dan N-gain pada kelas eksperimen dan kelas kontrol.

Tabel 1 Data Kemampuan Komunikasi Matematis

\begin{tabular}{|c|c|c|c|c|c|}
\hline \multirow[t]{2}{*}{ Kategori } & \multirow{2}{*}{$\begin{array}{l}\text { Data } \\
\text { Statistik }\end{array}$} & \multicolumn{3}{|c|}{ Eksperimen } & Kontrol \\
\hline & & Pretes & Postes & $\mathrm{N}$-gain & Pretes \\
\hline
\end{tabular}




\begin{tabular}{|c|c|c|c|c|c|c|c|}
\hline \multirow{3}{*}{ Tinggi } & $\bar{x}$ & 3,25 & 7,63 & 0,77 & 2,88 & 6,25 & 0,56 \\
\hline & SD & 1,49 & 1,06 & 0,15 & 1,46 & 1,91 & 0,26 \\
\hline & $\mathbf{N}$ & \multicolumn{6}{|l|}{8} \\
\hline \multirow{3}{*}{ Sedang } & $\overline{\boldsymbol{x}}$ & 1,75 & 6,75 & 0,68 & 1,42 & 5,08 & 0,48 \\
\hline & SD & 0,97 & 0,87 & 0,14 & 0,99 & 0,90 & 0,13 \\
\hline & $\mathbf{N}$ & \multicolumn{6}{|l|}{12} \\
\hline \multirow{3}{*}{ Rendah } & $\overline{\bar{x}}$ & 1,63 & 5,13 & 0,44 & 1,50 & 3,75 & 0.32 \\
\hline & SD & 1,06 & 0,83 & 0,11 & 0,92 & 2,12 & 0,25 \\
\hline & $\mathbf{N}$ & \multicolumn{6}{|l|}{8} \\
\hline \multirow{3}{*}{$\begin{array}{l}\text { Keselur } \\
\text { uhan }\end{array}$} & $\bar{x}$ & 2,14 & 6,54 & 0,64 & 1,82 & 5,04 & 0,45 \\
\hline & SD & 1,33 & 1,40 & 0,19 & 1,28 & 1,84 & 0,22 \\
\hline & $\mathbf{N}$ & \multicolumn{6}{|l|}{28} \\
\hline
\end{tabular}

Analisis skor pretes menggunakan uji kesamaan pretes dan analisis skor postes menggunakan uji perbedaan postes. Uji kesamaan postes bertujuan untuk melihat apakah kemampuan komunikasi matematis siswa sebelum pembelajaran diberikan pada kedua kelas sama secara signifikan. Uji perbedaan postes bertujuan untuk melihat apakah kemampuan komunikasi matematis siswa setelah pembelajaran diberikan pada kedua kelas berbeda secara signifikan. Sebelum data dianalisis terlebih dahulu dilakukan uji prasyarat analisis yaitu uji normalitas dan uji homogenitas. Dari hasil uji kesamaan pretes diketahui tidak terdapat perbedaan yang signifikan antara skor pretes kemampuan penalaran matematis siswa kelas eksperimen dan kelas kontrol. Dari hasil uji perbedaan postes diketahui terdapat perbedaan yang signifikan antara skor postes kemampuan penalaran matematis siswa kelas eksperimen dan kelas kontrol.

Rangkuman hasil uji perbedaan rataan skor $\mathrm{N}$-gain kemampuan komunikasi mateamatis disajikan pada Tabel 2 berikut.

Tabel 2 Uji Perbedaan Rataan Skor N-gain Kemampuan Komunikasi Matematis Keseluruhan Siswa

\begin{tabular}{|l|l|l|}
\hline \multicolumn{3}{|l|}{ t-test for Equality of Means } \\
\hline $\mathbf{t}$ & df & Sig. (2-tailed) \\
\hline 3,368 & 54 & 0,001 \\
\hline
\end{tabular}

Dari Tabel 2 di atas diketahui bahwa nilai Sig. (2-tailed) sebesar 0,001 $<\alpha=0,05$. Disimpulkan bahwa $\mathrm{H}_{0}$ ditolak, artinya peningkatan kemampuan komunikasi matematis siswa kelas eksperimen lebih baik daripada siswa kelas kontrol. Dengan demikian terbukti bahwa peningkatan kemampuan komunikasi matematis siswa yang mendapat pembelajaran accelerated learning lebih baik daripada siswa yang mendapat pembelajaran konvensional ditinjau dari keseluruhan siswa.

\section{Analisis Skor N-gain Kemampuan Komunikasi Matematis Berdasarkan KAM}

Rangkuman hasil uji perbedaan rataan skor N-gain kemampuan komunikasi mateamatis pada kategori KAM tinggi disajikan pada Tabel 3 berikut. 
Tabel 3 Uji Perbedaan Rataan Skor N-gain Kemampuan Komunikasi Matematis pada Kategori KAM Tinggi

\begin{tabular}{|l|l|}
\hline Statistik & Nilai \\
\hline Mann-Whitney U & 13,500 \\
\hline Z & $-1,954$ \\
\hline Asymp. Sig. (2-tailed) & 0,051 \\
\hline
\end{tabular}

Dari Tabel 3 di atas diketahui bahwa nilai Sig. (2-tailed) sebesar 0,051> $\alpha=0,05$. Disimpulkan bahwa $\mathrm{H}_{0}$ diterima, artinya peningkatan kemampuan komunikasi matematis siswa kelas eksperimen sama dengan siswa kelas kontrol pada kategori KAM tinggi. Dengan demikian diketahui bahwa peningkatan kemampuan komunikasi matematis siswa yang mendapat pembelajaran accelerated learning, tidak lebih baik daripada siswa yang mendapat pembelajaran konvensional pada KAM tinggi.

Rangkuman hasil uji perbedaan rataan skor $\mathrm{N}$-gain kemampuan komunikasi mateamatis pada kategori KAM sedang disajikan pada Tabel 4 berikut.

Tabel 4 Uji Perbedaan Rataan Skor N-gain Kemampuan Komunikasi Matematis pada Kategori KAM Sedang

\begin{tabular}{|l|l|}
\hline Statistik & Nilai \\
\hline Mann-Whitney U & 17,500 \\
\hline$Z$ & $-3,168$ \\
\hline Asymp. Sig. (2-tailed) & 0,002 \\
\hline
\end{tabular}

Dari Tabel 4 di atas diketahui bahwa nilai Sig. (2-tailed) sebesar 0,002 < $\alpha=0,05$. Disimpulkan bahwa $\mathrm{H}_{0}$ ditolak, artinya peningkatan kemampuan komunikasi matematis siswa kelas eksperimen lebih baik daripada siswa kelas kontrol pada kategori KAM sedang. Dengan demikian diketahui bahwa peningkatan kemampuan komunikasi matematis siswa yang mendapat pembelajaran accelerated learning lebih baik daripada siswa yang mendapat pembelajaran konvensional pada KAM sedang.

Rangkuman hasil uji perbedaan rataan skor $\mathrm{N}$-gain kemampuan komunikasi mateamatis pada kategori KAM rendah disajikan pada Tabel 5 berikut.

Tabel 5 Uji Perbedaan Rataan Skor N-gain Kemampuan Komunikasi Matematis pada Kategori KAM Rendah

\begin{tabular}{|l|l|}
\hline Statistik & Nilai \\
\hline Mann-Whitney U & 25,000 \\
\hline Z & $-0,741$ \\
\hline Asymp. Sig. (2-tailed) & 0,459 \\
\hline
\end{tabular}

Dari Tabel 11 di atas diketahui bahwa nilai Sig. (2-tailed) sebesar 0,459> $\alpha=0,05$. Disimpulkan bahwa $\mathrm{H}_{0}$ diterima, artinya peningkatan kemampuan komunikasi matematis siswa kelas eksperimen sama dengan siswa kelas kontrol pada kategori KAM rendah. Dengan demikian diketahui bahwa peningkatan kemampuan komunikasi matematis siswa yang mendapat 
pembelajaran accelerated learning tidak lebih baik daripada siswa yang mendapat pembelajaran konvensional pada KAM rendah.

\section{Pembahasan}

Penelitian ini bertujuan untuk mengkaji peningkatan kemampuan penalaran dan komunikasi matematis antara siswa yang mendapat pembelajaran accelerated learning dengan siswa yang mendapat pembelajaran konvensional ditinjau dari keseluruhan siswa dan berdasarkan KAM. Berdasarkan hasil analisis data yang telah disajikan sebelumnya, berikut ini akan diuraikan deskripsi dan interpretasi data hasil penelitian. Deskripsi dan interpretasi data penelitian dianalisis berdasarkan pada kemampuan penalaran matematis, kemampuan komunikasi matematis, pembelajaran accelerated learning dan kategori KAM siswa.

\section{Kemampuan Komunikasi Matematis siswa}

Berdasarkan hasil uji kesamaan pretes, diketahui bahwa tidak terdapat perbedaan skor pretes kemampuan komunikasi matematis siswa yang mendapat pembelajaran accelerataed learning dengan siswa yang mendapat pembelajaran konvensional. Hal ini menunjukkan bahwa kemampuan komunikasi matematis kedua kelas sebelum pembelajaran diberikan sama, sehingga adanya perbedaan peningkatan kemampuan komunikasi matematis kedua kelas memang benar disebabkan oleh pembelajaran yang diberikan.

Dari hasil penelitian ini terungkap bahwa ditinjau secara keseluruhan siswa, siswa yang mendapat pembelajaran accelerated learning memiliki rataan postes kemampuan komunikasi matematis yang lebih tinggi dibandingkan dengan siswa yang mendapat pembelajaran konvensional. Demikian juga dari hasil analisis skor N-gain kemampuan komunikasi matematis ditemukan bahwa peningkatan kemampuan penalaran matematis siswa yang mendapat pembelajaran accelerated learning lebih baik daripada siswa yang mendapat pembelajaran konvensional. Dilihat dari segi klasifikasi $\mathrm{N}$-gain, rataan $\mathrm{N}$-gain siswa yang mendapat pembelajaran accelerated learning berada pada klasifikasi sedang, demikian juga rataan $\mathrm{N}$-gain siswa yang mendapat pembelajaran konvensional berada pada klasifikasi sedang.

Pada kategori KAM tinggi walaupun tidak terdapat perbedaan yang signifikan untuk peningkatan kemampuan komunikasi matematis siswa yang mendapat pembelajaran accelerated learning dengan siswa yang mendapat pembelajaran konvensional, akan tetapi tetap terdapat selisih yang cukup besar antara kedua rataan $\mathrm{N}$-gain yaitu sebesar 0,21 . Rataan $\mathrm{N}$-gain siswa yang mendapat pembelajaran accelerated learning pada kategori KAM tinggi sebesar 0,77. Hal ini berarti Rataan N-gain siswa yang mendapat pembelajaran accelerated learning pada kategori KAM tinggi berada pada klasifikasi tinggi, sedangkan Rataan $\mathrm{N}$-gain siswa yang mendapat pembelajaran konvensional sebesar 0,56 berada pada klasifikasi sedang. Pada kategori KAM sedang peningkatan kemampuan komunikasi matematis siswa yang mendapat pembelajaran accelerated learning lebih baik daripada siswa yang mendapat pembelajaran konvensional.

Terdapat beberapa dugaan mengapa peningkatan kemampuan komunikasi matematis siswa yang mendapat pembelajaran accelerated learning lebih baik daripada siswa yang mendapat pembelajaran konvensional. Pertama. Pada tahap persiapan dalam pembelajaran 
accelerated learning, siswa diberikan tugas untuk membaca dengan pemahaman setiap materi yang akan dipelajari dan didiskusikan di kelas. Hal ini dapat membiasakan sekaligus mengasah kemampuan membaca siswa serta pemahaman siswa terhadap apa yang mereka baca. Kemampuan membaca dengan pemahaman suatu presentasi matematika tertulis ini merupakan salah satu dari indikator kemampuan komunikasi matematis yang dikemukakan oleh Sumarmo (Asmida, 2009). Dengan demikian, melalui tahapan ini siswa telah terbiasa melakukan proses komunikasi matematis.

Kedua. Pada tahap presentasi dalam pembelajaran accelerated learning, siswa diarahkan dan diberikan kesempatan untuk mendengarkan, berdiskusi dan menulis tentang matematika. Berkaitan dengan hal tersebut, melalui tahapan ini kemamampuan komunikasi matematis dapat ditingkatkan. Selain itu Pimm (Asmida, 2009), menyatakan bahwa anak-anak yang diberikan kesempatan untuk bekerja dalam kelompok dalam mengumpulkan dan menyajikan data, mereka menunjukkan kemajuan disaat mereka saling mendengarkan ide yang satu dan yang lain, mendiskusikannya bersama, kemudian menyusun kesimpulan yang menjadi pendapat kelompoknya. Ternyata mereka belajar sebagian besar dari berkomunikasi dan mengkonstruksi sendiri pengetahuan mereka.

Ketiga. Pembelajaran accelerated learning dalam pelaksanannya menuntut siswa menganalisis, mengemukakan ide matematis, presentasi dan membuat kesimpulan untuk menemukan konsep, prosedur dan prinsip matematika secara individual maupun kelompok. Melalui kegiatan berdiskusi siswa dilatih untuk mampu menjelaskan dan membuat pertanyaan matematika yang telah dipelajari. Selain itu, kemampuan siswa untuk menjelaskan ide, situasi dan gagasan matematis baik secara lisan maupun tulisan dapat dikembangkan. Ungkapan senada juga disampaikan Sumarmo (Asmida, 2009) yang mengungkapkan bahwa untuk memaksimalkan proses dan hasil belajar matematika, siswa perlu didorong untuk terlibat secara aktif dalam diskusi, siswa dibimbing untuk bisa bertanya serta menjawab pertanyaan, berpikir kritis, menjelaskan setiap jawaban yang diberikan, serta mengajukan alasan untuk setiap jawaban yang diajukan.

Pada kategori KAM rendah diketahui tidak terdapat perbedaan yang signifikan antara rataan $\mathrm{N}$-gain kemampuan komunikasi matematis siswa yang mendapat pembelajaran accelerated learning dengan rataan $\mathrm{N}$-gain kemampuan komunikasi matematis siswa yang mendapat pembelajaran konvensional. Hal ini menunjukkan peningkatan kemampuan komunikasi matematis siswa yang mendapat pembelajaran accelerated learning tidak lebih lebih baik daripada siswa yang mendapat pembelajaran konvensional.

Tidak terdapat perbedaan yang signifikan antara rataan $\mathrm{N}$-gain kemampuan komunikasi matematis siswa yang mendapat pembelajaran accelerated learning dengan rataan $\mathrm{N}$-gain kemampuan komunikasi matematis siswa yang mendapat pembelajaran konvensional, diduga disebabkan oleh beberapa faktor. Sama halnya dengan kemampuan matematis lainnya, kemampuan komunikasi matematis siswa dipengaruhi oleh faktor internal dan eksternal. Faktor internal berasal dari siswa sendiri seperti, kecerdasan, minat, bakat, dan kemauan serta motivasi diri terhadap proses pembelajaran. Faktor eksternal berasal dari luar diri siswa seperti, lingkungan keluaraga dan lingkungan sekolah (Hutagalung, 2009).

Kemampuan komunikasi matematis merupakan kemampuan matematika tingkat tinggi. Sebagaimana yang yang dikemukakan oleh Sumarmo (Asmida, 2009), bahwa kemampuan komunikasi matematis merupakan kemampuan yang dapat menyertakan dan memuat berbagai kesempatan untuk berkomunikasi dalam bentuk : merefleksikan benda-benda nyata, gambar, dan diagram ke dalam ide matematis; menjelaskan ide, situasi, dan relasi matematik, secara lisan atau 
tulisan; menyatakan peristiwa sehari-hari dalam bahasa atau simbol matematika; mendengarkan, berdiskusi, dan menulis tentang matematika; membaca dengan pemahaman suatu presentasi matematika tertulis; membuat konjektur, menyusun argumen, merumuskan definisi dan generalisasi; menjelaskan dan membuat pertanyaan matematika yang telah dipelajari. Berdasarkan hal tersebut diduga siswa pada kategori KAM rendah akan mengalami kesulitan.

\section{Pembelajaran Accelerated Learning}

Hasil analisis data penelitian menunjukkan bahwa kemampuan penalaran dan kemampuan komunikasi matematis siswa yang mendapat pembelajaran accelerated learning lebih baik daripada siswa yang mendapat pembelajaran konvensional. Hasil analisis data juga menunjukkan bahwa peningkatan kemampuan penalaran dan kemampuan komunikasi matematis siswa yang mendapat pembelajaran accelerated learning lebih baik daripada siswa yang belajar menggunakan pembelajaran konvensional. Hasil temuan ini mengindikasikan bahwa pembelajaran accelerated learning memberikan pengaruh yang positif terhadap kemampuan penalaran dan kemampuan komunikasi matematis siswa. Hal ini disebabkan pada pembelajaran accelerated learning siswa dituntut melakukan persiapan belajar, bernalar, berdiskusi dan latihan, menganalisis, pendugaan, mempresentasikan dan membuat kesimpulan untuk menemukan konsep, prosedur dan prinsip matematika secara individual maupun kelompok. Melalui aktivitas seperti itu, kemampuan penalaran dan komunikasi siswa akan berkembang dengan baik.

Terjadinya aktivitas mental dalam menemukan konsep, prosedur dan prinsip matematika sangat bergantung pada pertanyaan-pertanyaan yang disajikan dalam lembar kerja siswa (LKS). Pertanyaan-pertanyan yang diajukan harus mendorong siswa melakukan persiapan belajar, bernalar, dan mengkomunikasikan ide. Berhasil atau tidaknya siswa menemukan konsep, prosedur dan pinsip matematika tergantung pula pada bentuk pertanyaan-pertanyaan yang diajukan guru secara lisan pada saat proses pembelajaran. Pertanyaan-pertanyaan yang diajukan harus terjangkau oleh pikiran siswa. Hal tersebut agar tidak membuat siswa gagal dalam menemukan konsep. Hal ini dimaksudkan agar siswa tidak merasa frustasi, yang dapat mengakibatkan mereka kehilangan semangat dan kepercayaan diri dalam menemukan konsep matematika.

Kemampuan penalaran dan komunikasi matematis pada kategori KAM tinggi walaupun tidak terdapat perbedaan yang signifikan anatara siswa yang mendapat pembelajaran accelerated learning dengan siswa yang mendapat pembelajaran konvensional, akan tetapi tetap terdapat selisih yang cukup besar antara kedua rataan $\mathrm{N}$-gain yaitu sebesar 0,21. Hal ini menunjukkan bahwa pada kategori KAM tinggi, pembelajaran accelerated learning dapat mengembangkan kemampuan penalaran dan komunikasi matenatis matematis siswa.

Pada kategori KAM sedang, peningkatan kemampuan penalaran dan komunikasi matematis siswa yang mendapat pembelajaran accelerated learning, lebih baik daripada siswa yang mendapat pembelajaran konvensional. Temuan ini menunjukkan bahwa, pada kategori KAM sedang pembelajaran accelerated learning dapat mengembangkan kemampuan penalaran dan komunikasi matematis siswa.

Pada kategori KAM rendah, peningkatan kemampuan penalaran matematis siswa yang mendapat pembelajaran accelerated learning, lebih baik daripada siswa yang mendapat pembelajaran konvensional. Temuan ini menunjukkan bahwa, pada kategori KAM rendah pembelajaran accelerated learning dapat mengembangkan kemampuan penalaran matematis siswa. Untuk kemampuan komunikasi matematis didapat fakta bahwa tidak terdapat perbedaan 
yang signifikan antara rataan $\mathrm{N}$-gain siswa yang mendapat pembelajaran accelerated learning dengan rataan $\mathrm{N}$-gain siswa yang mendapat pembelajaran konvensional. Hal ini menunjukkan pada kategori KAM rendah, peningkatan kemampuan komunikasi matematis siswa yang mendapat pembelajaran accelerated learning, tidak lebih lebih baik daripada siswa yang mendapat pembelajaran konvensional. Hal ini mengindikasikan bahwa untuk kategori KAM rendah, pembelajaran accelerated learning tidak memberikan kontribusi yang lebih baik terhadap peningkatan kemampuan komunikasi matematis siswa.

Lebih baiknya kemampuan penalaran dan komunikasi matematis siswa yang belajar menggunakan pembelajaran accelerated learning dibandingkan siswa yang belajar menggunakan pembelajaran konvensional juga disebabkan karena pembelajaran accelerated learning mendorong perkembangan aktual dan perkembangan potensial siswa. Tingkat perkembangan aktual tampak ketika siswa menyelesaikan tugas-tugas atau memecahkan berbagai masalah secara mandiri. Berkaitan dengan menyelesaikan tugas dan memecahkan berbagai masalah secara mandiri, hal ini bersesuaian dengan salah satu prinsip dari pembelajaran accelerated learning yang dikemukakan oleh Meier (2002). Prinsip tersebut yaitu, belajar berasal dari mengerjakan pekerjaan itu sendiri. Belajar paling baik adalah belajar dalam konteks, misalnya untuk belajar berenang harus dengan berenang, cara bernyanyi dengan bernyanyi, cara menjual dengan menjual, dan seterusnya. Pengalaman yang konkret atau nyata dapat menjadi guru yang jauh lebih baik daripada sesuatu yang hipotesis dan abstrak.

Tingkat perkembangan potensial tampak ketika siswa menyelesaikan tugas-tugas di bawah bimbingan guru ataupun melelui proses diskusi dengan teman. Pada pembelajaran accelerated learning, setiap siswa diarahkan dan diberikan kesempatan seluas-luasnya untuk bertanya dan berdiskusi dengan guru maupun dengan teman. Hal ini bersesuaian dengan salah satu prinsip pembelajaran accelerated learning, yaitu kerjasama membantu proses belajar. Usaha belajar yang baik mempunyai landasan sosial, dan siswa biasanya belajar melalui interaksi dengan teman-temannya. Kerja sama antar siswa akan mempercepat pembelajaran, sehingga suatu komunitas belajar selalu lebih baik hasilnya daripada belajar sendiri-sendiri.

\section{Kemampuan Awal Matematis (KAM)}

Berdasarkan hasil penelitian diketahui, dlihat dari rataan $\mathrm{N}$-gain antar kategori KAM terdapat perbedaan rataan peningkatan kemampuan penalaran dan komunikasi matematis baik siswa yang mendapat pembelajaran accelerated learning maupun konvensional. Peningkatan kemampuan penalaran matematis pada siswa yang mendapat pembelajaran accelerated learning, antara KAM tinggi dengan sedang terdapat perbedaan sebesar 0,05, antara KAM tinggi dengan rendah terdapat perbedaan sebesar 0,32 dan antara KAM sedang dengan rendah terdapat perbedaan sebesar 0,27. Peningkatan kemampuan penalaran matematis pada siswa yang mendapat pembelajaran konvensional, antara KAM tinggi dengan sedang terdapat perbedaan sebesar 0,15, antara KAM tinggi dengan rendah terdapat perbedaan sebesar 0,46 dan antara KAM sedang dengan rendah terdapat perbedaan sebesar 0,31. Temuan ini menunjukkan bahwa semakin baik KAM yang dimiliki siswa semakin baik pula peningkatan kemampuan penalaran matematisnya. Hal ini mengindikasikan ada hubungan antara KAM yang dimiliki siswa dengan peningkatan kemampuan penalaran matematisnya.

Peningkatan kemampuan komunikasi matematis pada siswa yang mendapat pembelajaran accelerated learning, antara KAM tinggi dengan sedang terdapat perbedaan sebesar 0,09, antara KAM tinggi dengan rendah terdapat perbedaan sebesar 0,33 dan antara KAM sedang dengan rendah terdapat perbedaan sebesar 0,24. Peningkatan kemampuan komunikasi matematis pada 
siswa yang mendapat pembelajaran konvensional, antara KAM tinggi dengan sedang terdapat perbedaan sebesar 0,08, antara KAM tinggi dengan rendah terdapat perbedaan sebesar 0,16 dan antara KAM sedang dengan rendah terdapat perbedaan sebesar 0,24. Temuan ini menunjukkan bahwa semakin baik KAM yang dimiliki siswa semakin baik pula peningkatan kemampuan komunikasi matematisnya. Hal ini mengindikasikan ada hubungan antara KAM yang dimiliki siswa dengan peningkatan kemampuan komunikasi matematisnya.

Berdasarkan hasil penelitian juga diketahui skor rataan $\mathrm{N}$-gain kemampuan penalaran matematis siswa kelompok tinggi, sedang, dan rendah pada pembelajaran accelerated learning lebih tinggi daripada rataan $\mathrm{N}$-gain kemampuan penalaran matematis siswa kelompok tinggi, sedang, dan rendah pada pembelajaran konvensional. Hal yang sama berlaku pula untuk rataan $\mathrm{N}$-gain kemampuan komunikasi matematis. Rataan N-gain kemampuan komunikasi matematis siswa kelompok tinggi, sedang, dan rendah pada pembelajaran accelerated learning lebih tinggi daripada rataan $\mathrm{N}$-gain kemampuan penalaran matematis siswa kelompok tinggi, sedang, dan rendah pada pembelajaran konvensional. Temuan ini juga mengindikasikan kemampuan awal matematis siswa memberikan pengaruh yang signifikan terhadap kemampuan penalaran dan komunikasi matematis siswa.

Uraian di atas memberikan gambaran bahwa kemampuan awal matematis memberikan kontribusi yang baik dalam pemerolehan pengetahuan baru. Hal ini sesuai dengan salah satu prinsip pembelajran accelerated learning yang dikemukakan oleh Meier (2002). Dinyatakan bahwa belajar adalah berkreasi, bukan mengkonsumsi. Pengetahuan bukanlah suatu yang diserap oleh siswa, melainkan sesuatu yang diciptakan oleh siswa. Pembelajaran terjadi jika seorang siswa memadukan pengetahuan dan keterampilan baru ke dalam struktur yang telah ada dalam dirinya. Hal ini berkaitan dengan teori konstruktivisme yang berpandangan bahwa belajar merupakan kegiatan membangun pengetahuan yang dilakukan sendiri oleh siswa berdasarkan pengamalam atau pengetahuan yang dimiliki sebelumnya. Berdasarkan hal diatas, dapat disimpulkan bahwa pemerolehan pengetahuan baru sangat ditentukan oleh pengetahuan awal (prior knowledge) siswa, apabila pengetahuan awal siswa baik maka akan berakibat pada pemerolehan pengetahuan yang baik pula.

\section{E. KESIMPULAN DAN REKOMENDASI}

Berdasarkan data penelitian dan hasil analisis data diperoleh beberapa kesimpulan terkait dengan hipotesis-hipotesis penelitian, antara lain (1) Peningkatan kemampuan komunikasi matematis siswa yang mendapat pembelajaran accelerated learning secara signifikan lebih baik daripada siswa yang mendapat pembelajaran konvensional ditinjau dari keseluruhan siswa.; (2) Peningkatan kemampuan komunikasi matematis siswa pada kategori KAM tinggi yang mendapat pembelajaran accelerated learning secara signifikan tidak lebih baik daripada siswa yang mendapat pembelajaran konvensional.; (3) Peningkatan kemampuan komunikasi matematis siswa pada kategori KAM sedang yang mendapat pembelajaran accelerated learning secara signifikan lebih baik daripada siswa yang mendapat pembelajaran konvensional.; (4) Peningkatan kemampuan komunikasi matematis siswa pada kategori KAM rendah yang mendapat pembelajaran accelerated learning secara signifikan tidak lebih baik daripada siswa yang mendapat pembelajaran konvensional.

Berdasarkan hasil penelitian yang diperoleh, maka rekomendasi penelitian yang disampaikan, antara lain (1) Pembelajaran accelerated learning hendaknya dijadikan sebagai alternatif pembelajaran di jenjang SMP dalam upaya mengembangkan kemampuan komunikasi matematis.; (2) Diharapkan kepada peneliti lainnya agar bisa menggunakan populasi yang lebih 
luas dengan sampel lebih banyak, dengan tujuan memperkecil kesalahan dan mendapatkan hasil yang lebih akurat.; (3) Bagi guru yang akan menerapkan pembelajaran accelerated learning agar memperhatikan aspek pengetahuan prasyarat yang dimiliki siswa. Guru hendaknya memberikan remediasi kepada siswa dengan kemampuan rendah agar dapat terlibat secara aktif dalam diskusi.; (4) Dalam upaya implementasi pembelajaran accelerated learning di sekolah menengah pertama, direkomendasikan kepada para pengambil kebijakan pendidikan untuk mengadakan perubahan-perubahan terhadap paradigma pembelajaran matematika yang selama ini kurang sesuai dengan kaidah-kaidah pembelajaran accelerated learning. Misalnya, tentang pandangan terhadap matematika, siswa dan guru. Dalam pandangan pembelajaran accelerated learning , matematika tidak dipandang sebagai suatu ilmu/ bidang kajian yang sudah jadi dan disajikan dalam bentuk akhir, tetapi dipandang sebagai sesuatu yang harus dikonstruksi sendiri oleh siswa.

\section{DAFTAR PUSTAKA}

Badan Penelitian dan Pengembangan (Balitbang). (2011). Laporan Hasil TIMSS 2007. Kementrian Pendidikan dan Kebudayaan.

Badan Penelitian dan Pengembangan (Balitbang). (2011). Laporan Hasil PISA 2009. Kementrian Pendidikan dan Kebudayaan.

Darhim. (2004). Pengaruh Pembelajaran Matematika Kontekstual terhadap Hasil belajar Matematika Siswa Sekolah Dasar. Disertasi UPI. Bandung : Tidak diterbitkan.

Diani. (2010). Peningkatan Kemampuan Penalaran dan Komunikasi dengan Pendekatan Creative Problem Solving melalui media GeoGebra. Tesis. Bandung: SPs UPI.

Hutajulu. (2010). Peningkatan kemampuan pemahaman dan penalaran matematik siswa sekolah menengah atas melalui model pembelajaran inkuiriterbimbing. Tesis. Bandung: SPs UPI.

Meier, D. (2002). The Accelerated Learning. Bandung: Kaifa.

Ruseffendi, H.E.T (2005). Dasar-Dasar Penelitian Pendidikan dan Bidang Non Eksata Lainnya. Bandung: Tarsito.

Suhendar. (2007). Meningkatkan kemampuan komunikasi dan koneksi matematik siswa SMP yang berkemampuan rendah melalui pendekatan kontekstual dengan pemberian tugas tambahan. Tesis. Bandung: SPs UPI.

Suherman, E. (2004). Evaluasi Pembelajaran Matematika. Bandung: JICA.

Turmudi. (2008). Landasan Filsafat dan Teori Pembelajaran Matematika (berparadigma Eksploratif dan Investigasi). Jakarta: Leuser Cita Pustaka.

Turmudi. (2012). Teachers' Perception Toward Mathematics Teaching Innovation in Indonesian Junior High School: An Exploratory Factor Analysis. Journal of Mathematics Education. August 2012, Vol. 5, No. 1, pp. 97-120. [Online]. Tersedia:http://educationforatoz.org. [11 Oktober 2012]. 
